\title{
THE PROBLEMS OF HIGH-RISE CONSTRUCTION IN ST. PETERSBURG
}

\author{
Leonid LAVROV ${ }^{\mathrm{a}}$, Fedor PEROV \\ St Petersburg State University of Architecture and Civil Engineering, \\ Department of Architecture, Vtoraja Krasnoarmejskaja ul. 4, St. Petersburg, 190005, Russian Federation \\ E-mails: ${ }^{a}$ leonid.lavrov@gmail.com; ${ }^{b}$.perov@gmail.com (corresponding author) \\ Received 05 March 2016; accepted 09 May 2016
}

\begin{abstract}
St. Petersburg's strict limit on building height existed until the 1960s. A small loosening of restrictions occurred only at the end of the 19th century, which formed the "horizontal" silhouette of the city with a few spire accents, domes and factory chimneys. In the USSR during the 1960s, a multi-storey building system began to develop. As this inclusive unification spread throughout Leningrad, 9-storey, 12-storey, 16-storey residential buildings became widespread. The population's attitude to them was quite critical. When Russia became a market economy country, St. Petersburg began to actively feel the influence of globalization in the architectural and construction industries. A consequence of the development of new technologies has become the mass construction of residential buildings that are 22-25 floors in height (including buildings closely located to the historical center). Fire safety issues were discovered, and problems concerning soil conditions were uncovered. The high buildings' influence on the protected center landscapes were very negatively received by citizens. In spite of the approved building regulations, there are many problematic situations; for example, the project of a 400-meter skyscraper next to the monument of Smolniy Cathedral provoked many debates in the city.
\end{abstract}

Keywords: architecture, city centre, cultural heritage, heritage protection, historical landscape, large scale housing, Soviet period architecture, high-rise construction.

\section{Introduction}

In Russia there is no common classification of buildings in height, but the following varieties of floors are popular:

- Multi-storey buildings -6 or more floors;

- High-rise - 11-16 floors;

- High-rise - more than 16 floors.

Based on these classifications, we can conclude that the history of high-rise construction in St. Petersburg is about 20-30 years old.

The present thesis analyzes and delves into the issue of the popularization of high-rise buildings in St. Petersburg, in a way that focuses on considering the features of architectural and construction traditions of the city in a specific environment (defining ground conditions and climatic characteristics).

\section{Prehistory (1703-1960's).}

St. Petersburg was founded in 1703 . The city was created on the swamp banks of the Neva delta with no relief differences. Until 2012, the cathedral of the Peter and
Paul Fortress was the tallest in the city, and its spire height reached $122.5 \mathrm{~m}$. For centuries, the height of city buildings was not allowed to exceed 23.5 meters (right up to the eaves of Winter Palace) (11 yards). Only church bells, domes and spires, factory chimneys, and, in the second part of the century, a few glass skylights, could be exceptions. St. Isaac's Cathedral, whose height reached $101.5 \mathrm{~m}$ (Hallmann 1978), became a significant high-rise accent in 1858 (Fig. 1).

At the end of the $19^{\text {th }}$ century height restrictions were softened, but when the Zinger Company wanted to build the first skyscraper in Russia with 11 stories, topped with a tower, on the main street of St. Petersburg, they were not allowed to do it (Mumford 1936). Instead, they built only an illusion of a tall building - a 6 floor house, with a mansard on the seventh floor and a glass tower in the corner. The administration was against such a modernist dome in front of the classic dome of Kazan Cathedral, but the architect was supported by the Academy of Arts. During these years, such 


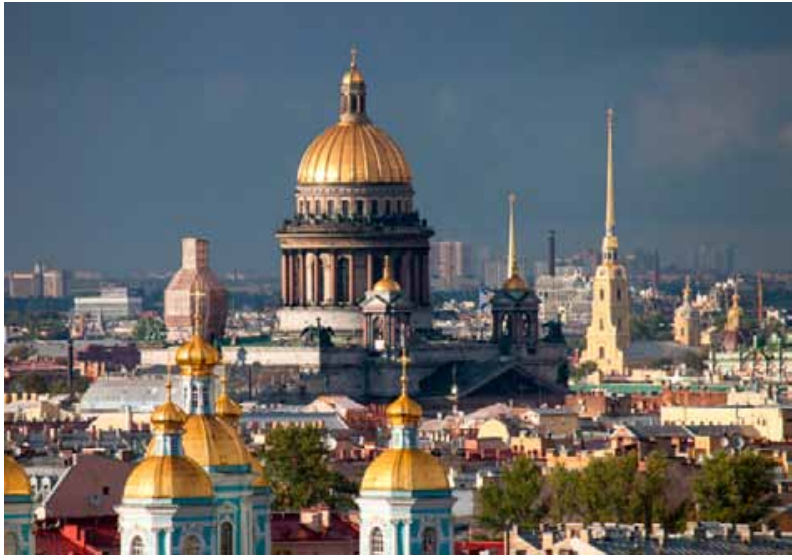

Fig. 1. St. Isaac's Cathedral a significant high-rise accent of St. Petersburg in 1858 (Blinov 2014)

5-6-storey buildings with mansards appeared in the center and the suburbs (Lisovskij 2004). For successful construction on swamp ground, people used 6-8 meter wooden piles, but this system was not always effective: during the period when it was in use, St. Isaac's Cathedral bent and sagged for a few tens of centimeters, and the foundations of the Rostral Columns also had to be corrected.

The architectural and construction activity in the first centuries of its existence turned the wilderness area of St. Petersburg into one of the most beautiful architectural cities in the world (Shvidkovsky 2007). European involvement was widely drawn upon, and foreign architects made great contributions to the development of the city, which was considered to be a good example of successful globalization in $18^{\text {th }}-19^{\text {th }}$ centuries (Lisovskij 2004). In the year 1990, the historic center of St. Petersburg, with an area of several tens of kilometers, became a part of the UNESCO World Heritage List (Historic Centre of Saint Petersburg).

\section{The Soviet high-rise building (1960-1993)}

These years can be characterized in the USSR as a period of mass construction of economical types of houses, in different districts of the city. This was a tough system of management and planning, which used a limited range of structural planning decisions. In the late 1950s, the popular 5-storey buildings with no elevators required extensive engineering development in new territories (Baranov, Bylinkina 1962). These 9, 12, and (sometimes) 16 storey houses in St. Petersburg, as well as all throughout Russia, appeared to save land (Syreyschikov 1972) and give the city more apartments (Fig. 2).

High-rise buildings were a completely a new type of housing - both for specialists and ordinary people. In addition to the analysis of Russian results, a lot of attention was paid on the study of international experi-

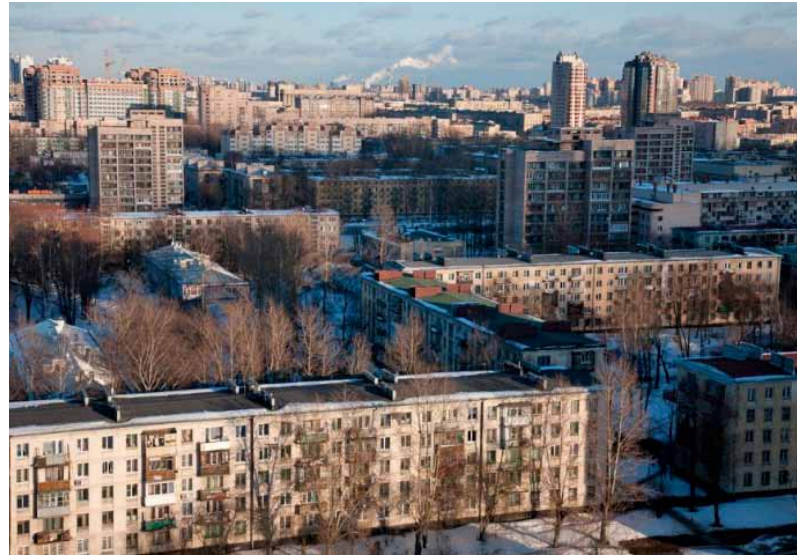

Fig. 2. USSR economical types of houses (Moskovsky district 2015)

ence. Not only did various publications appear, but also, different symposia involving the participation of foreign scientists were organized (Maksai 1979). Specialists bought technologies in small volumes, and numerous research organizations were involved in developing the sphere. Much attention was paid on the pragmatic aspects, such as fire-prevention systems (Raeva et al. 1976) and the particularities of sanitary conditions inside buildings (Syreyschikov 1972). Strict attention was focused on the building foundation of Leningrad (Olhova et al. 1967). It turned out that the ancient and acceptably strong sedimentary and moraine soil was located at a depth of 20-30 m (it was taken into consideration when making tunnels for the Petersburg Underground). Near the surface there is weak and heterogeneous, water-saturated silty-clay soil. Such soil causes a large settling of the ground, that usually lasts for tens and even hundreds of years. People had to use piles of up to 20-30 meters (Shukurova 1977). In difficult situations the piles did not help - they were "sucked in". They had to stop the construction of the 18-storey tower on Constitution Square in the 1970s because the foundation of high-rise buildings began to set into the ground. The planned

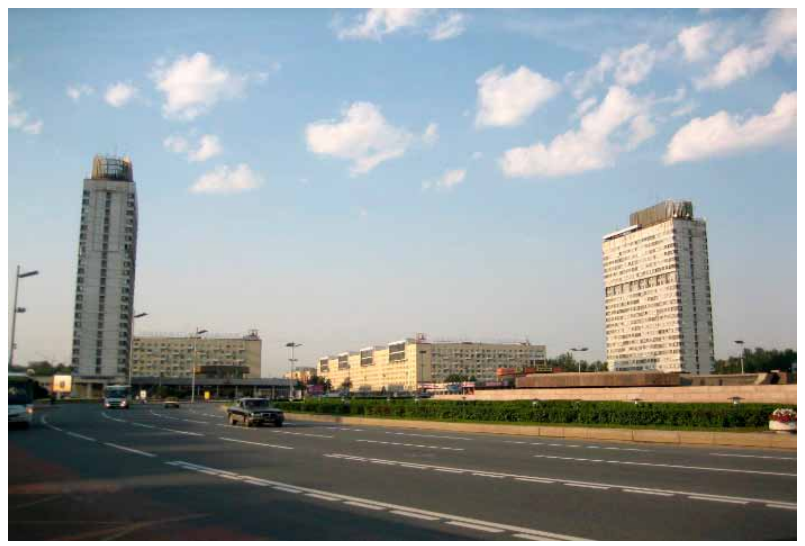

Fig. 3. 22-storey buildings in Victory Square 
height of the dormitory on Korablestroiteley Street was not built for the same reason. During the same years, several 22-storey buildings were built (in Victory Square and Smolenka) (Fig. 3).

\section{Nowadays}

In early 1990s, the beginning of the transition to a market economy and globalization took place in Russia. Not only were international relations activated, but also, the volumes of imports of construction materials increased rapidly, and the widespread development of foreign design and construction experience started. European and Asian design and construction firms now work in St. Petersburg (Lavrov, Johenning 2014). The choice of architectural planning and design decisions became based not on prescriptions of planning organizations, but on the real estate market conditions. High-rise buildings became an evident feature of urban landscapes. At the beginning of 2015, there were 353 buildings that were either newly finished or under construction, the former at a height from 75 to 100 meters, and the latter a height of 21 to 100 meters.

In actuality, these comprise a small number of buildings finished during these years. There were problems that significantly complicated design and planning decisions - there was an increase in the amount of necessary engineering equipment, and, as a consequence, large financial costs. In some cases, there were architectural features problems that didn't take landscape features into consideration, and caused a conflict.

The construction of the "Mont Blanc" multifunctional center started in 2003. In advertising, they talked about this innovative project of elite housing, and how its height would ensure marvelous views of the historic center from the windows. The maximum building height was $74.5 \mathrm{~m}$, and during the object construction, it was found to be one of the worst Petersburg construction mistakes of recent years. In May 2006, the St. Petersburg Planning Council rejected the cons-

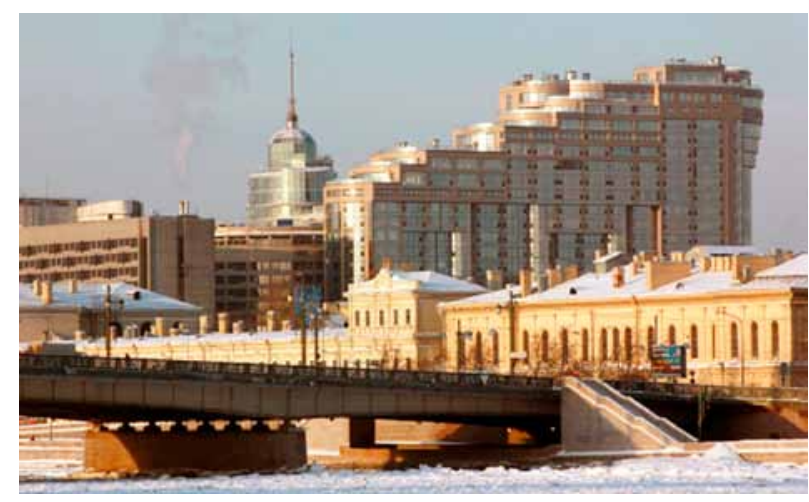

Fig. 4. "Mont Blanc" building distort the historical panorama of the Neva River (Shishkin 2012) truction project of "Mont Blanc" (Fig. 4), and said that the building would distort the historical and architectural panorama of the Neva River. The developers tried to make some adjustments (that still retained the same height), but it was not successful. Even today the building on the Neva is the object of sharp criticism.

Additionally, in 2009 there was a situation when the authorities made the developer dismantle two top floors of the building for the new Exchange in the west of Vasilievsky Island, to bring the size of construction to the St. Petersburg zoning law requirements (KGA 2009). The dismantling cost 6 million dollars.

The international response took the 396 meters tall skyscraper near Smolniy Cathedral that was conceived as a dominant complex of Okhta Centre (known until March 2017 as Gazprom City) (Fig. 5).

It was supposed to be put into operation in 2012, but the situation worsened when the authorities decided to hold an international project competition, and as a result many public debates took place. In July 2006, he St. Petersburg Union of Architects claimed that the skyscraper would ruin the city's appearance. The Union of Architects of Russia said the same, noticing that the competition was breaking international and national rules and regulations. In protest, the Union boycotted the contest, and all of the projects were from other countries (Lavrov, Semenzov 2013). Three of the four of the foreign architects invited as jury members (Norman Foster, Kiso Kurokawa and Rafael Vinoli) left of the jury to express their negative attitude towards the competition task and tried to show the city administration the danger of the "aggressive influence of high-rise buildings on the city silhouette." Also, they noticed that the high skyscraper construction in the vicinity of the historic city center was destroying its harmony. In June 2007, the 31st UNESCO World Heritage Committee session met in New Zealand, and it also was against the skyscraper, considering the possible consequences of skyscraper construction on the area. As a result, the

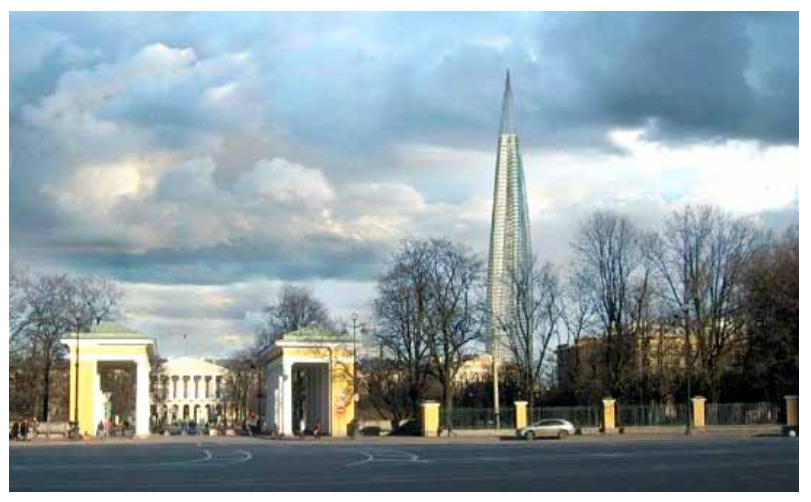

Fig. 5. Okhta Centre (known until March 2017 as Gazprom City) would ruin the city's appearance 


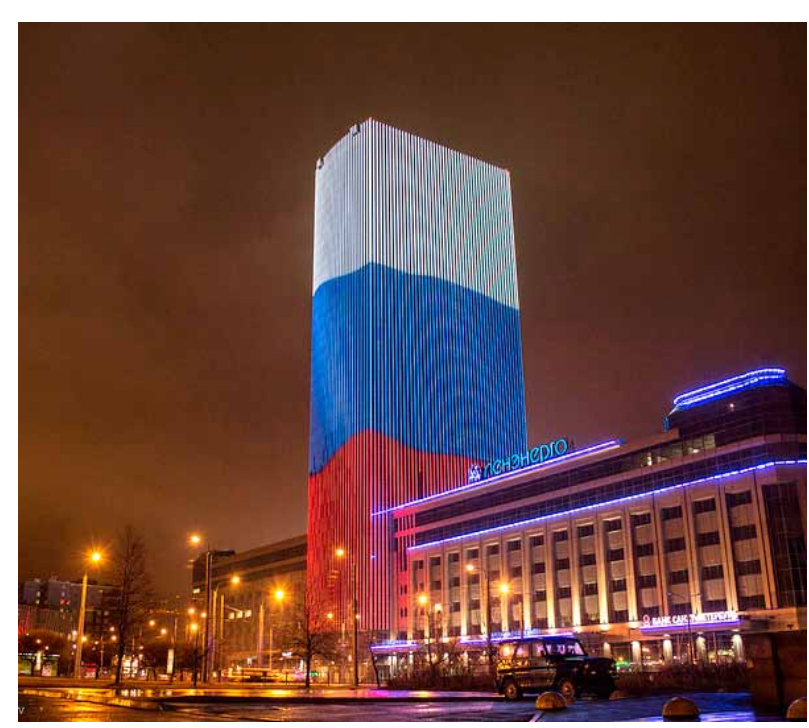

Fig. 6. The "Leader Tower" is located at a distance from the historical center

(Business center 2014)

project wasn't realized, but the positive potential of globalization for the protection of historical and cultural heritage appeared.

In 2011, "Gazprom" bought the land for the construction of an office building in the new part of the city on the north shore of the Gulf of Finland. "Lahtacenter" - the headquarters of the company "Gazprom," is being constructed at a $9 \mathrm{~km}$ distance from the historic center of the city. The commissioning year is 2018 . The number of floors -86 . The skyscraper will have a height of $462 \mathrm{~m}$, and it will be viewable from some city center places. However, the potential influence on the existing historical silhouette could be hidden by mist over water. Presently, they are constructing the foundation. It will be installed on 264 deep piles, with each pile 82 meters in depth and 2 meters in diameter. Due to very difficult ground conditions and the structures above ground, components of engineering systems and construction costs demanded a significant share of the budget. Obviously, "Lahta- center" will be a unique building, and other high-rise buildings in St. Petersburg will yield to it in many ways.

The "Leader Tower" complex was put into operation in 2013. It is located at a distance from the center of Constitution Square, but its silhouette can be seen in the alignment of one of the three central radial avenues. The compact building is located on the place where an 18 -storey building was attempted to be built in Soviet times. The foundation of the Soviet skyscraper was dismantled and a new construction began in its place. Now, as the tallest office building in St. Petersburg (140 $\mathrm{m}$ altitude), the skyscraper has 42 floors. It has some innovations: on the top floor there is an observa- tion place with panoramic views of the historic center and helicopter landings.

In 2012, the media façade was tested, but this angered the residents of houses near the skyscraper who could not fall asleep at night, and drivers who were distracted by the bright light. So, the media facades were switched off until the advertising structure received installation permission (Fig. 6).

The residential complex "Alexander Nevskiy", located upstream on the Neva River, is the highest building, having 36 floors and a height of $124 \mathrm{~m}$. The top-floor apartments are attractive, as the Peter and Paul Fortress and St. Isaac's Cathedral are visible from them in good weather, so these apartments are the most popular. Usually, the luxury apartments are located on the top floors, and customers book them during the period of construction because this type of housing is exclusive for St. Petersburg, given its flat relief. There are few apartments of this type and they cost from \$ 1 million.

It's very complicated to build a skyscraper. A highrise building has a different foundation and a different frame. It is necessary to take the wind into consideration. Even a $130 \mathrm{~m}$ window leaf should be specifically designed.

A separate issue concerns the electric power supply. For a skyscraper, it is necessary to make a reservation of electricity and heat supply from the city network, in addition to thinking about additional energy sources.

No doubt, a high-rise building has more energy consumption. To construct a high-rise building is more expensive due to expensive engineering and fire protection systems. Moreover, there are more elevators and stairs, as opposed to the quantity in ordinary residential housing. So, there are lots of unsuitable territories for high-rise housing. To compare the suitable territories for low-rise housing versus high-rise, it's obvious that for low-rise housing, 70-80\% of territories are suitable, but in high-rise buildings this number is much lower. As a result, specialists and residents have had many complaints.

In any case, the government will meet to discuss the question of the possibility of building skyscrapers in St. Petersburg soon, and there are discussions to offer a set maximum allowable height of 75 meters.

\section{The European experience in high-rise construction in the historical cities}

There is significant experience in high-rise construction in the European historical cities. A big variety of solutions that influences the historical centers development are offered, depending on the specific situation and priorities, facing the city. Taking into consideration the international experience, we have the 
opportunity to analyze the practice of St. Petersburg critically and express an opinion about the best ways of city development.

High-rise construction problems in the historical centers could be subdivided into two large groups: a high-rise building influence on the quality of people's lives and the influence on the image and identity of the city. The start of high-rise construction in St. Petersburg is supposed to be the post-war reconstruction phase when new high-rise apartment blocks appeared on the territories destroyed by the war. Besides the technical aspects (design solution, fire safety, the information about the influence of the number of floors on comfort decrease, and on sanitary conditions of living environment in multi-storey buildings attracted attention. The scientists of the University of Architecture and Civil Engineering in collaboration with specialists from the scientific part of LenNIIProekt Research Institute carried out local research (Fig. 7).

As a result, large number of cities residents, as it turned out, prefer the apartments, located not above the 8th floor, and if possible - at the level of the 3rd - 5th floors. However, the high-rise construction is actively developing in the historical cities of Europe due to economic factors (the effective use of land, building density increasing), and a matter of prestige. High-rise construction has significant opportunities to change the image of the city (Herlyn 1972). In many European cities new buildings significantly influenced on the panorama and the image of the historical city (Frankfurt, London, Paris partly). A radical change in the identification of people with their architectural surroundings shows the German city - Frankfurt on the Main. Before the Second World War the city has a traditional historical center (Fig. 8).

Practically, the city was wiped out after the bombing of the allies, and right after the war, the Germans began to restore everything carefully. However, the city got the new destination - to be the largest financial center of the country and Europe. Skyscrapers began to grow in proximity with the historical center. A population survey showed that the majority of citizens are against this construction, the rapid change of the landscape has destroyed the possibility of their identity.

Several decades passed, generations changed, the city got a new silhouette and new architecture. And surprisingly, the latest survey showed that the residents of the city are satisfied with the new look of it. They suppose that the recovery of the historical center on the background of the new sharp silhouette of the skyscrapers is a comfortable environment for them (Jetenko 1967). It is a new identification of people and the architectural environment of the city (Fig. 9).

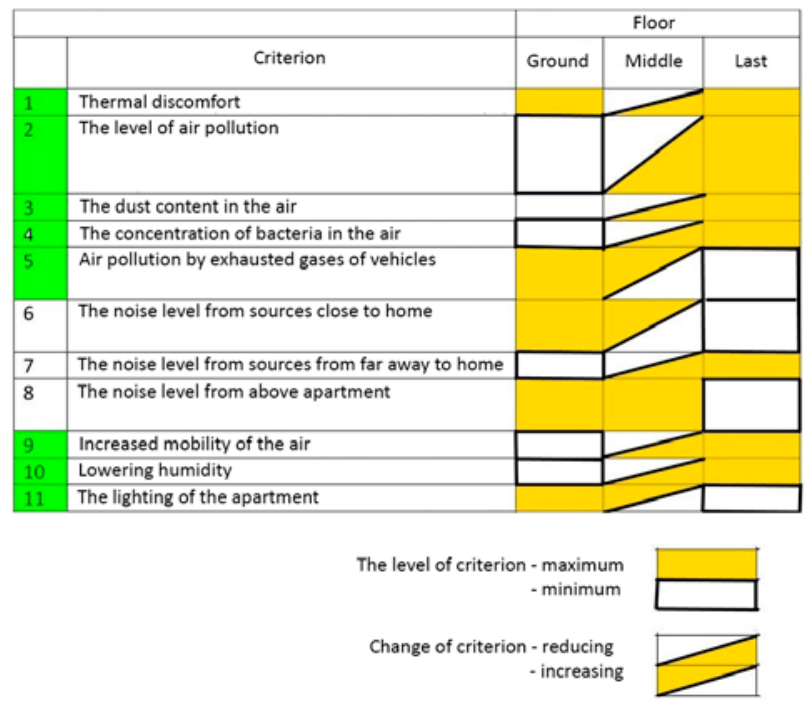

Fig. 7. Influence of the number of floors on comfort decrease

The identification qualities of the historical center of Frankfurt are completely lost but in London they changed significantly. Everyone knows the City district, a downtown. Large financial companies impose their conditions and requirements for buildings; usually they need high-rise unconventional buildings to demonstrate their financial power. The buildings erected by famous architects, are interesting themselves, but absolutely ignore the historical environment. As a result, the city silhouette has no system. St. Paul's Cathedral silhouette has stopped playing its role of an urban dominant (Fig. 10).

The Tower of London turned into a doll house on a background of modern monumental architecture. It's hard to struggle with it because it needs to play a role of a world financial center.

However, many historical cities use high-rise construction, bringing it beyond the visual connection to the historical center, saving the historical identity of the city center. Assessing the experience of multi-storey construction and high-rise buildings in the European cities, special attention should be paid to the Viennese

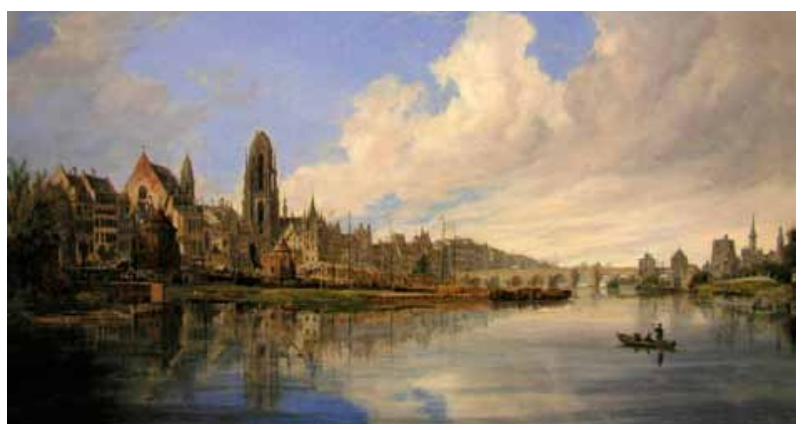

Fig. 8. Historical panorama of Frankfurt (Germany) 


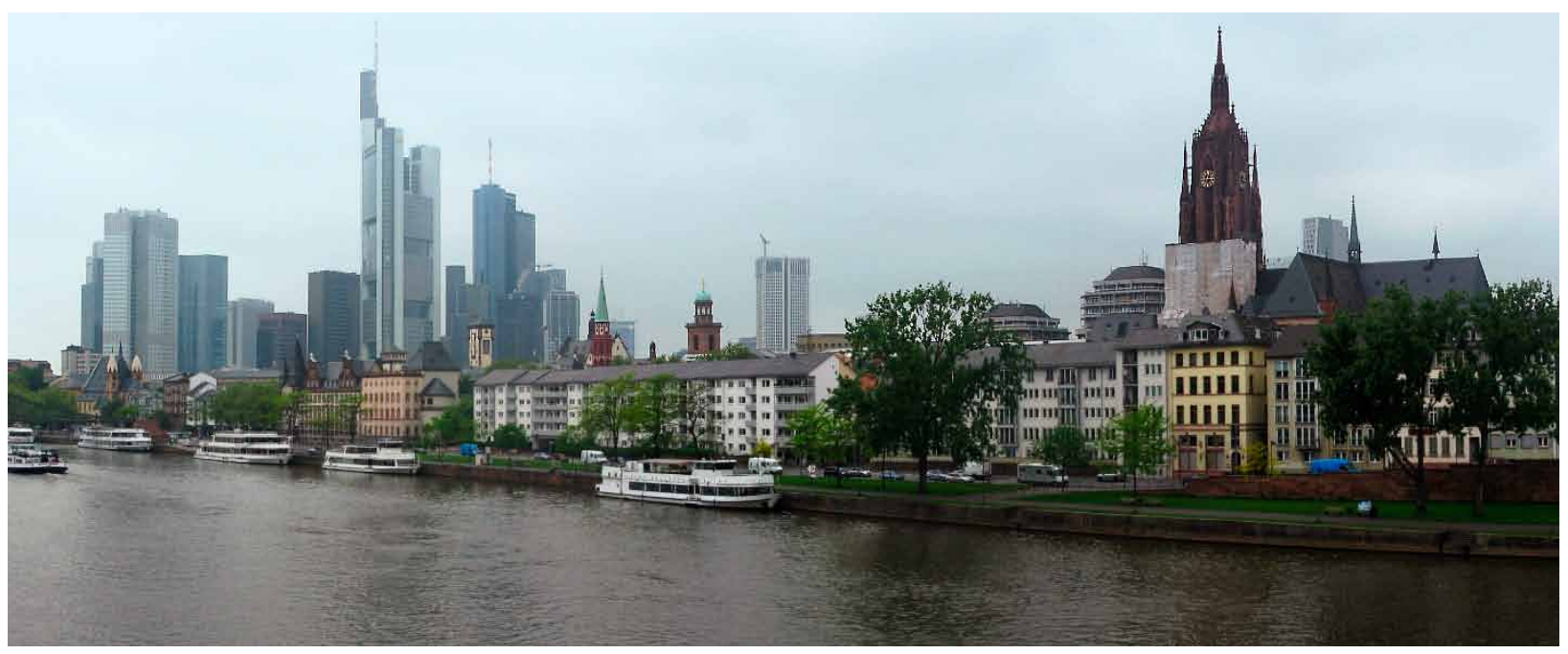

Fig. 9. Reconstruction of the center of Frankfurt (Germany). The new city silhouette formation

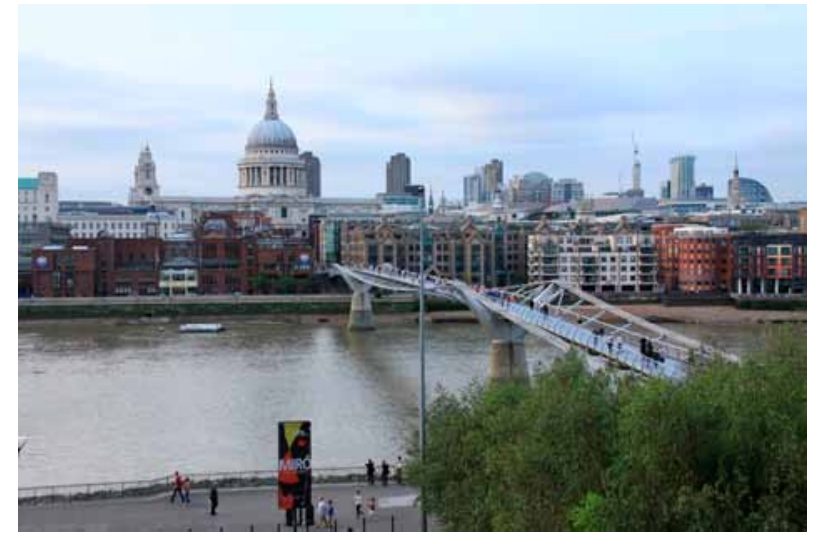

Fig. 10. The changing of London silhouette. The contrast of modern and historic architecture

city builders achievements. The new high-rise business and residential buildings are located in the new district beyond 2 inflows of the Danube far from the old Vienna with St. Stephen's Cathedral. The same situation is in Rome (Fig. 11), Amsterdam and Brussels.

All the examples of the different types of modernization, the new high-rise construction in the historical cities show the diversity of the problem and the necessity of individual ways for different specific construction cases. However, this process should be evolutionary, not to destroy what cannot be restored. All the inevitable changes should take place gradually, without breaking the rules and principles of the city development, giving its residents the opportunity not to lose their identity with the "homeland."

\section{Conclusions}

The historic center silhouette of the city, formed centuries ago, has exceptional value. These traditional features cause St. Petersburg to strongly affect the perception of architectural solutions.

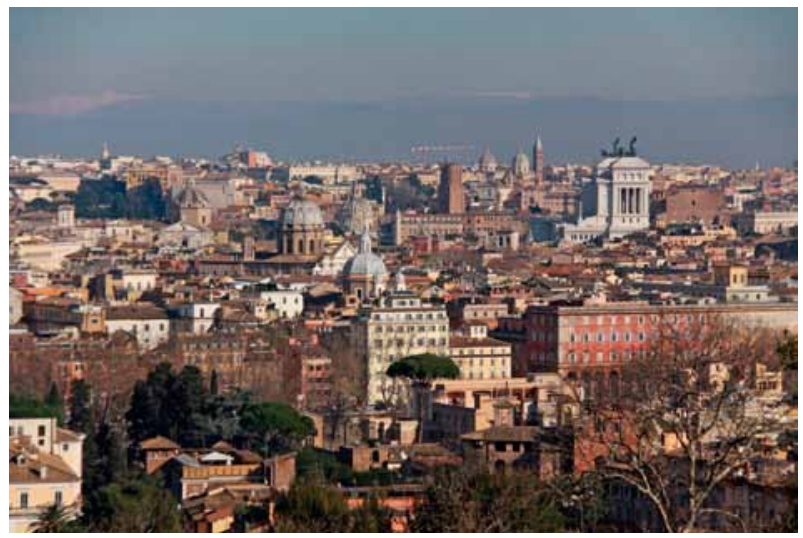

Fig.11. Silhouette of Rome without modern dominants

The city emotionally and traditionally isn't ready for high-rise construction. For 200 years, St. Petersburg had strict regulations limiting the height of buildings to $23.4 \mathrm{~m}$ (the eave height of the Winter Palace). In the near future, there will be no skyscraper constructions in St. Petersburg.

The analysis of city development showed that the high-rise construction seems to be inexpedient in the center of St Petersburg. First of all, due to the necessity to save historical appearance of the city, protected by UNESCO. There are the existing identification characteristics of the city that do not fit high-rise buildings.

High-rise building can be located in the new social centers of the city away from the historical center, like in Vienna. In this case, they are the means of identification characteristics of new districts.

In all cases, high-rise building in St. Petersburg should have a restricted distribution, taking into consideration the negative influence on people life quality.

The regional features should also be considered in St. Petersburg. Here the buildings options are limited depending on: 
- zoning laws, the historical and architectural considerations;

- the ground conditions.

Taking into account financial considerations: residential buildings higher than 30 floors (higher than 100 meters) aren't economically profitable.

If these problems will be solved, high-rise construction will become very popular. It will be important for a monocentric structure of the city and the formation of city silhouette from the Gulf of Finland.

High-rise construction will bring new dynamics to the development of construction technologies, and the creation of new modern living places for citizens.

\section{References:}

Baranov, N.; Bylinkina, N. 1962. Istorija Sovetskoj arhitektury: 1917-1958 [The History of Soviet Architecture: 1917-1958]. Moscow: Gosstrojizdat.

Blinov, A. 2014. Saint- Petersburg. And from our window... [online], [cited October 07 2014]. Available from Internet: http://anton-blinov.livejournal.com/36227.html

Business centre "Leader Tower" [online]. 2014 [cited 25 May 2014]. Available from Internet: http://spb.arendator.ru/ objects/8753-leader_tower-2/

Hallmann, G. 1978. Leningrad: Kunstgeschichtliche Städtebücher. Leipzig: VEB E.A. Seemann-Verlag.

Herlyn, U. 1972. Wohnen im Hochhaus. Stuttgart: K.Kraemer Verlag.

Jetenko, V. 1967. Zhilye doma povyshennoj jetazhnosti v zarubezhnom stroitel'stve [Residential High-rise Buildings in Foreign Construction]. Moscow: Strojizdat. RF

KGA (Committee for Architecture and Urban Development). 2009. Pravila zemlepol'zovaniya i zastroiki (tekstovaya chast' $i$ skhemy) [Regulations of land use and development (text and schemes)]. Committee for Architecture and Urban Development, Saint Petersburg, RF [online], [cited 16 December 2015]. Available from Internet: http://www. kgainfo.spb.ru/pages/pzz/pzz.html

Lavrov, L.; Johenning, H. 2014. Architektur in SanktPetersburg, in Architekturführer Sankt- Petersburg. Berlin: DOM publishers.

Lavrov, L.; Semenzov, S. 2013. Globalization in architecture: three examples from Saint Petersburg, World Applied Sciences Journal (Problems of Architecture and Construction) 23: $25-30$.

Lisovskij, V. 2004. Arhitektura Peterburga. Tri veka istorii [The Architecture of St. Petersburg. Three centuries of history]. Sankt-Peterburg: Slavija.

Maksai, D. 1979. Proektirovanie zhilyh zdanij [The Design of Residential Buildings]. Moscow: Strojizdat.

Moskovsky district, 7-10 SURD. The architectural concept [online]. 2015 [cited 05 January 2015]. Available from Internet: http://dom.spbren.ru/proekti/9/34968.html?t=2

Mumford, L. 1936. Ot brevenchatogo doma do neboskreba [From the wooden house to a skyscraper]. Moscow: Publishing House of the USSR Academy of Architecture. RF
Olhova, A.; Maklakova, T.; Gelberg, L., et al. 1967. Zhilye doma povyshennoi etazhnosti (otechestvennyi opyt) [High-rise houses. (domestic experience)]. Moscow: Stroyizdat.

Raeva, V.; Sadov, A.; Chirkov, V. 1976. Transportnye kommunikacii i jevakuacionnye puti $v$ mnogojetazhnyh zhilyh domah [Transport Communications and Emergency Routes in Multi Storey Residential Buildings]. Moscow: Strojizdat.

Shishkin, A.; Ratnikov, D. 2012. Experts of the "Karpovka" named the worst new building in St. Petersburg [online], [cited 27 December 2012]. Available from Internet: http://kanoner. com/2012/12/27/87793/

Shukurova, A. 1977. Novye teoreticheskie problemy proektirovaniya vysotnykh zdanii. Obzor [The new theoretical problems of tall buildings design. Review]. Moscow: TsNTI po grazhdanskomu stroitel'stvu i arkhitekture.

Syreyschikov, V. 1972. Arkhitekturno-gigienicheskie kachestva zhilykh domov povyshennoi etazhnosti. Obzor [Architectural and hygienic quality of residential high-rise buildings]. Moscow: TsNTI po grazhdanskomu stroitel'stvu i arkhitekture.

Shvidkovsky, D. 2007. Russian architecture and the West. USA: Yale University Press.

\section{LEONID LAVROV}

$\mathrm{PhD}$, Professor, Department of Architecture, Chair of Architectural Design, Saint Petersburg State University of Architecture and Civil Engineering, Saint Petersburg, Russia. Research interests: urban design and planning, history of architecture.

\section{FEDOR PEROV}

$\mathrm{PhD}$, Professor, Department of Architecture, Chair of Architectural Design, Saint Petersburg State University of Architecture and Civil Engineering. Research interests: urban design and planning, post-Soviet cities. 